\title{
CZY ŚWIAT JEST KLINIKĄ? O PROCESACH MEDYKALIZACJI WE WSPÓŁCZESNYCH SPOŁECZEŃSTWACH KAPITALISTYCZNYCH. RECENZJA KSIĄŻKI MICHALA NOWAKOWSKIEGO, MEDYKALIZACJA I DEMEDYKALIZACJA. ZDROWIE I CHOROBA W CZASACH KAPITALIZMU ZDEZORGANIZOWANEGO, WYDAWNICTWO UNIWERSYTETU M. CURIE-SKLODOWSKIEJ, LUBLIN 2015 (155 STRON)
}

Troska o własne zdrowie towarzyszy ludziom od dawna, jednak w ostatnich dekadach XX w. i na początku XXI w. granica między tym, co jest zdrowiem i tym, co jest chorobą zaczęła się zacierać. Jedną z przyczyn tego zjawiska są nasilające się procesy medykalizacji życia społecznego i choć jego początków można doszukiwać się w pracach starożytnych uczonych, to dopiero sekularyzacja i oświecenie, zastępując wiarę nauką, umożliwiły rozprzestrzenianie się tych procesów. Najprościej medykalizację można zdefiniować jako przekształcanie czegoś niemedycznego w coś medycznego; czegoś, co dotychczas traktowane było jako naturalny stan, cecha czy zachowanie a obecnie jest definiowane w kategoriach zaburzenia, syndromu czy choroby. Marcin M o ska le w i c z charakteryzuje to zjawisko, uwzględniając trzy wymiary (2012: 26). Pierwszy z nich wpisuje się w zawartość treściową niemal wszystkich istniejących obecnie definicji medykalizacji. Jest nim definiowanie zjawisk niemedycznych za pomocą języka medycyny, a tym samym włączanie ich pod jurysdykcję instytucji medycznych (np. zmienność nastrojów u kobiet, wywołana cyklem miesiączkowym, obecnie jest opisywana jako Premenstrual Symdrome, PMS). Drugi wymiar podkreśla ekspansję medycyny na inne obszary życia, poprzez rozprzestrzenianie się terminologii medycznej w sferach pozamedycznych (np. dzieci w obszarze edukacji przestały być traktowane jako niezdolne czy niegrzeczne, a zaczęły być postrzegane przez pryzmat zaburzeń psychologiczno-behawioralnych, takich jak Attention-Deficit Hyperactivity Disorder, ADHD). Jako trzeci wymiar Moskalewicz

* Dr, Zakład Socjologii, Wydział Nauk o Zdrowiu, Uniwersytet Medyczny w Łodzi, ul. Lindleya 6, 90-131 Łódź; e-mail: magdalena.wieczorkowska@umed.lodz.pl. 
opisuje namnażanie stanów chorobowych, co może być związane z działalnością i praktykami przemysłu farmaceutycznego (np. suplement diety Sesja, który ma na celu wspomaganie pamięci i koncentracji. Z jednej strony jest to przykład tzw. human enhancement, ulepszenia zdrowotnego, z drugiej jednak, może kreować przekonanie, że trudności w koncentracji, a tym samym gorsze wyniki na studiach są patologią o podłożu biologicznym, a preparat może ją złagodzić).

Zjawisko medykalizacji od lat jest przedmiotem zainteresowania, zarówno teoretyków, jak i badaczy społecznych w wielu krajach (m.in. w Stanach Zjednoczonych, Wielkiej Brytanii, Francji, we Włoszech). W Polsce zagadnienie to zyskuje popularność od kilkunastu lat, jednak większość opracowań to artykuły o charakterze teoretycznym, przeglądowym, w dużej mierze relacjonujące pozycje zagraniczne $\mathrm{z}$ tego zakresu.

Medykalizacja i demedykalizacja. Zdrowie i choroba w czasach kapitalizmu zdezorganizowanego Michała Nowakowskiego jest pierwszą na polskim rynku pozycją książkową, poświęconą w całości temu zagadnieniu. Autor przedstawia medykalizację $w$ perspektywie historycznej, opisuje ją również w kontekście współczesnych procesów społeczno-gospodarczych, charakterystycznych dla „społeczeństw «późnej nowoczesności» (Giddens 2010), «płynnej nowoczesności» (Bauman 2006), czy wreszcie «ery postindustrialnej» (Bell 1975) lub «kapitalizmu zdezorganizowanego» (Hall 1989, za: Jung 1997: 715; Lash, Urry 1987)" (N ow a k ow sk i 2015: 142). Jej niewątpliwym atutem jest próba opisu tego zagadnienia, zarówno w oparciu o literaturę anglojęzyczną, jak również poprzez odwołanie się do publikacji polskich socjologów medycyny. Tym samym książka daje obraz procesów medykalizacji we współczesnych rozwiniętych gospodarkach kapitalistycznych, niewiele mówiąc o tym, jak owe procesy przebiegają w Polsce (czego powodem jest brak badań własnych oraz nikły stan badań nad medykalizacją w naszym kraju), nie uwzględnia też kulturowych uwarunkowań tych procesów. Lektura książki nie daje odpowiedzi na pytanie, czy i jak przebiegają procesy medykalizacji w krajach arabskich i azjatyckich.

Jak pisze autor we Wstępie: „W książce przedstawiony zostanie pogląd, iż to, w jaki sposób laicy i profesjonaliści definiują zdrowie i chorobę, jest efektem procesów medykalizacji i demedykalizacji, kształtowanych w warunkach kapitalizmu zdezorganizowanego. $\mathrm{W}$ toku tych procesów, na poziomie ponadjednostkowym wytwarzana jest «kultura terapeutyczna», a na poziomie jednostkowym - człowiek o «zmedykalizowanej» tożsamości. Co więcej uważam, że procesy medykalizacji i demedykalizacji można potraktować jako coś w rodzaju marksowskiej «nadbudowy» w stosunku do «bazy», jaką stanowi kapitalizm zdezorganizowany. Jeśli pojawiające się głosy, że lekarze i inni eksperci od zdrowia są nowymi kapłanami obiecującymi zbawienie, a healthism zastępuje tradycyjne religie uznamy za nieprzesadzone, to czy można powiedzieć, że wizja zbawienia poprzez obsesyjne nieraz dbanie o zdrowie stało się nowym «opium dla ludu»?" (N ow a kowski 2015: 10). W kolejnych rozdziałach książki opisuje 
Czy świat jest kliniką? O procesach medykalizacji we współczesnych społeczeństwach... 149

perspektywę makrostrukturalną, w ramach której odwołuje się do takich koncepcji, jak kapitalizm zdezorganizowany, późna nowoczesność, ponowoczesność, które kształtują współczesne procesy medykalizacji, by w końcowych rozdziałach wspomnieć o mikrospołecznym wymiarze procesów medykalizacji.

Rozdział początkowy jest poświęcony genezie pojęcia medykalizacji, jego rozwojowi oraz krytyce. Autor podkreśla, że najwcześniejsze rozważania miały charakter analiz historycznych i pokazywały medykalizację przez pryzmat rozwoju instytucji medycznych (S zarszewski 2007). Zwraca także uwage na wartościujący charakter tego pojęcia, dając przykłady autorów i definicji niekrytycznych, pozytywnych oraz negatywnych. Te pierwsze wiążą medykalizację $\mathrm{z}$ ogólnym postępem naukowym, z osiagnnięciami medycyny $\mathrm{w}$ walce $\mathrm{z}$ chorobami, te drugie zaś podkreślają ,przemedykalizowanie” (overmedicalization) jako efekt nadmiernej ekspansji medycyny, wywołujący negatywne konsekwencje w wymiarze społecznym i jednostkowym. W swej książce Nowakowski kilkakrotnie stwierdza, że medykalizacja jest procesem pozytywnym, choć w publikacji więcej jest dowodów na jej negatywne oddziaływanie.

W dalszej części odwołuje się do prac Davisa, który akcentował różnorodność medykalizowanych zjawisk poddawanych analizie. Są to: 1) zachowania dewiacyjne; 2) naturalne procesy życiowe; 3) problemy życiowe; 4) biomedyczne ulepszenia ciała (N o w a k o w s k i 2015: 19). Na koniec tego rozdziału Nowakowski dokonuje konceptualizacji pojęcia i proponuje, aby medykalizację rozumieć jako zjawisko przyjmujące trzy formy: 1) patologizację, która jest rozumiana jako zawłaszczanie przez medycynę i opisywanie w kategoriach medycznych stanów i zachowań, określanych wcześniej jako złe, niemoralne, dewiacyjne; 2) asystowanie, definiowane przez autora jako czynienie z naturalnych procesów w cyklu życia człowieka zaburzeń w sensie medycznym; 3) ulepszanie, czyli wkraczanie medycyny w obszary ludzi zdrowych, by uczynić ich zdrowszymi (N o w a k o w sk i 2015: 21). W ostatnią formę implicite jest wpisane założenie, artykułowane w dalszych częściach książki, czytelnikowi nieznającemu problematyki socjologii medycyny mogące umknąć, że zdrowie i choroba nie są pojęciami przeciwstawnymi, a raczej tworzą pewnego rodzaju kontinuum oraz, że można czuć się zdrowym mimo obiektywnie występujących schorzeń i na odwrót - uważać się za chorego mimo braku obiektywnych symptomów choroby.

Drugi rozdział autor w całości poświęca historycznej analizie procesu medykalizacji oraz kształtowania się podejść teoretycznych i badawczych wobec niego. Rekonstruuje kolejne etapy tworzenia się wczesnego modelu medykalizacji, który początkowo rozwijał się nie za sprawą socjologów medycyny, lecz psychiatrów, atakujących i krytykujących uprawianą przez siebie dyscyplinę. Nurt antypsychiatrii ukształtował, obecne do dziś, stereotypowe oblicze medykalizacji jako zjawiska pejoratywnego. Jednym z najostrzejszych krytyków w ramach tego nurtu był psychiatra Thomas S za s z, który w swoich pracach (m.in. 2007, 2010) podkreślał arbitralność kryteriów diagnostycznych oraz negatywnie oceniał 
rozwiązywanie problemów społecznych poprzez czynienie z nich zaburzeń psychicznych. W podobnym tonie wypowiadała się Barbara W o o t to n, pokazująca, jak instytucje socjalne oddają pole instytucjom medycznym (1959). Następnie autor rekonstruuje ewolucję pojęcia „medykalizacja” w kolejnych dekadach, odwołując się do prac Eliota Freidsona i Irvinga Zoli, przybliżając tym samym czytelnikom źródła „imperializmu” profesji medycznych. Koncepcja ta jest istotna, gdyż współczesny model medykalizacji mocno osłabia pozycję instytucji oraz profesji medycznych w kreowaniu jej procesów, punkt ciężkości przesuwając w stronę rynku farmaceutycznego, mediów, ruchów społecznych, grup pacjentów oraz indywidualnych aktorów. Jatrogeniczność działań medycznych powoduje, że medycyna staje się głównym zagrożeniem dla zdrowia fizycznego i psychicznego obywateli, co opisuje Nowakowski, odwołując się do poglądów Ivana Illicha. Rozdział kończy przywołanie prac i postaci niekwestionowanego autorytetu w tej dziedzinie, amerykańskiego socjologa medycyny Petera Conrada. Jego pierwsza książka poświęcona była zaburzeniu określanemu jako ADHD i wpisywała się w nurt medykalizacji dewiacji. Jej wczesny model jawi się jako proces makrostrukturalny (tak też jest opisywany; brak tu refleksji na temat konsekwencji „,imperializmu” profesji medycznych w odniesieniu do relacji lekarz - pacjent, o czym pisała Sokołowska, 1986), chrakteryzujący się rozrostem jurysdykcji medycznej na obszary podlegające innym instytucjom (społecznym, prawnym, edukacyjnym).

Trzeci rozdział wprowadza perspektywę zdezorganizowanego kapitalizmu, rozumianego jako rozpad dotychczasowych znaczników kapitalizmu powojennego (klasa, przemysł, państwo narodowe), wzrost znaczenia struktur ponadnarodowych, przy jednoczesnej decentralizacji państw narodowych (czynnik egzogenny) oraz rosnące znaczenie klasy usługowej (czynnik endogenny). Nowakowski odwołuje się tu także do pojęć charakterystycznych dla autorów postmodernistycznych (Bauman, Baudrillard), wprowadzając chaos konceptualny dotyczący tego, w którą fazę rozwoju społeczno-gospodarczego wpisują się procesy medykalizacji. Ustalenie wzajemnych relacji między pojęciami „późnej nowoczesności”, „płynnej nowoczesności”, „,ery postindustrialnej” i „,kapitalizmu zdezorganizowanego" określiłoby miejsce medykalizacji w tych koncepcjach, pozwoliłoby również przybliżyć jej naturę, którą Conrad ujmuje jako proces społeczno-kulturowy (1992: 211), z niezwykle ważną determinantą jaką się staje zmienna ekonomiczna.

W ramach nowego modelu medykalizacji Nowakowski odwołuje się do prac Conrada, które bez wątpienia wpisują się w ten model oraz prac Adele Clarke i współautorów, używających terminu „biomedykalizacja” dla podkreślenia, że jest to proces napędzany poprzez rozwój nauki i technologii. Przyglądając się bliższym charakterystykom, dokonywanym przez zespół pod przewodnictwem Clarke, można odnieść wrażenie, że biomedykalizacja jest procesem jakościowo innym od medykalizacji i powinna być rozpatrywana jako jej kolejny etap. Jak 
Czy świat jest kliniką? O procesach medykalizacji we współczesnych społeczeństwach... 151

pisze Clarke, biomedykalizacja to ,złożone, wielokierunkowe procesy medykalizacji, które obecnie są rekonstytuowane poprzez pojawiające się formy społeczne i praktyki wysoce stechnologizowanej naukowej biomedycyny" (C o n r a d 2007: 14). Oczywiście, trudno nie znaleźć ich wspólnych cech, ale zasadne wydaje się wyodrębnienie biomedykalizacji jako kolejnego modelu, podobnie jak to miało miejsce w przypadku modelu wczesnego, napędzanego przez dominację profesji medycznych oraz nowego modelu mającego swe źródło w różnorodnych rozproszonych siłach, mających często sprzeczne interesy (np. koncerny farmaceutyczne i stowarzyszenia pacjentów).

Czym zatem charakteryzują się procesy medykalizacji współcześnie? Kolejne podrozdziały książki Nowakowskiego kreślą złożony obraz i dynamikę tych procesów, przeplatających się z procesami demedykalizacji. Jest ona najczęściej rozumiana jako proces przeciwstawny medykalizacji, polegający na czynieniu czegoś, co dotychczas było medyczne, czymś niemedycznym. Potocznie często określa się ten proces jako „medyczne odczarowanie”. Pisząc o tych przeciwstawnych procesach, Nowakowski podkreśla, że opozycja jest pozorna, bowiem, podczas gdy jedna sfera jest medykalizowana, inna podlega demedykalizacji. Jest to obraz prawdziwy, choć niepełny. W 2011 r. ukazała się praca, której autor twierdzi, że medykalizacja/demedykalizacja powinna być traktowana jako zmienna ciagła, również w odniesieniu do tego samego przypadku (H a lfm a n n 2011). Proponuje model poziomów (makro-, mezo- i mikropoziom) i wymiarów (dyskursy, praktyki, jednostki i aktorzy) medykalizacji/demedykalizacji, na podstawie których można zobrazować dialektykę tych procesów. Halfmann dokonuje analizy konkretnego przypadku, aborcji, pokazując, że to samo zjawisko może być jednocześnie medykalizowane (np. na poziomie makro, poprzez dyskursy) i demedykalizowane (na poziomie mikro, poprzez praktyki i aktorów społecznych). W książce Nowakowskiego zabrakło odwołań do tej nośnej ramy analitycznej, a propozycję Halfmanna warto zaprezentować ze względu na walory poznawcze - przedstawia złożoność współczesnych procesów medykalizacji/demedykalizacji.

Wracając do zagadnień medykalizacji, omawianych przez Nowakowskiego, trzeba stwierdzić, że dokonuje on niezwykle drobiazgowego przeglądu niemal wszystkich jej wymiarów. Jego zdaniem medykalizacja nie musi mieć charakteru odgórnego (top-down), ale często przybiera postać procesu oddolnego (bottom-up), z pominięciem kontekstu medycznego. Autor:

1. Pokazuje, jak zmienia się obraz medycyny i opieki zdrowotnej (z modelu opiekuńczego przekształca się w model biznesowy, korporacyjny), a tym samym, jak ewoluuje obraz pacjenta (z chorego staje się klientem, na którym można zarobić). Warto wspomnieć, że ugruntowuje to redefinicję kategorii zdrowia jako produktu stechnologizowanej medycyny, którego można mieć mniej lub więcej, w zależności od zmiennych socjodemograficznych, ale przede wszystkim ekonomicznych. Zdrowie staje się towarem, który można nabywać na rynku medycznym, powiększając tym samym jego zasób. 
2. Przedstawia nową sytuację profesjonalistów medycznych, głównie lekarzy, którzy stracili swą autonomię i władzę nad pacjentami (tzw. ,proletaryzacja” lekarzy) (N ow a ko w s ki 2015: 63). Lekarze muszą odnaleźć się w nowej rzeczywistości, w której pacjent często dysponuje bardzo rozległą (choć nie zawsze rzetelną) wiedzą medyczna, a tym samym oczekuje traktowania go jako partnera w procesie leczenia, w rzeczywistości, w której koncerny farmaceutyczne próbują przekonać do swych produktów, często używając nieczystych działań; wreszcie w rzeczywistości, w której równie ważny jak dobro pacjenta jest rachunek ekonomiczny placówki, w której lekarz pracuje. Rozważania są tu prowadzone na poziomie makro i mikro, gdzie lekarz dla wielu pacjentów (szczególnie starszych, gorzej wykształconych, mających mniejszy dostęp do wiedzy medycznej i placówek medycznych) nadal stanowi autorytet.

3. Pokazuje drugą stronę omawianej relacji pacjenta, a może raczej konsumenta usług medycznych, który jawi się jako dobrze poinformowany, często roszczeniowy, autonomiczny w swoich decyzjach i wyborach zdrowotnych. Autor promuje tu jednak ważną i ciekawą tezę, w jakim stopniu pacjent jest rzeczywiście niezależny, w jakim zaś jego wybory i decyzje są podyktowane korzystaniem z innych ,autorytetów" i źródeł, które - mając swe ukryte cele - umiejętnie manipulują informacją kreując lęk i czyniąc zdrowe osoby chorymi. Jörg B le ch (2006) sparafrazowal powiedzenie, charakteryzujące dawne podejście medycyny pisząc, że obecnie dla każdej pigułki znajdzie się chory („,There is an ill for every pill”).

5. Opisuje rolę koncernów farmaceutycznych i firm biotechnologicznych w kreowaniu procesów medykalizacji - odwołuje się tu do pojęcia „kompleksu medyczno-przemysłowego" autorstwa Lynn Payer, które doskonale oddaje istote praktyk tzw. Big Pharmy. Zagadnienia omawiane w tym podrozdziale - manipulowanie statystykami, „chorobotwórstwo” (disease mongering), traktowanie ryzyka jako tożsamego z choroba, pokazywanie łagodnych symptomów jako groźnych dla zdrowia - mieszczą się w szerszym procesie, opisywanym w literaturze jako farmaceutykalizacja (Willi a m s i in. 2011; A brah a m 2010; Wi e c zork ow s k a 2012), jednak pojęcie to nie jest przez autora używane. Szeroko opisuje związki przemysłu farmaceutycznego ze światem nauki, pokazując m.in., jak medyczny ghostwriting pozwala wprowadzać na rynki i sprzedawać leki o wattpliwych wartościach terapeutycznych oraz podając przykłady manipulowania wynikami testów klinicznych leków.

6. Omawia alternatywne eksperckie systemy, dostępne na rynku usług zdrowotnych, które traktowane są często jako przejaw demedykalizacji - ideologia indywidualizmu, kultura terapeutyczna, medycyna alternatywna i komplementarna, samoleczenie, promocja zdrowia i wpisująca się w nią ideologia healthismu. Nowakowski skłania się jednak ku temu, by traktować je - całkiem słusznie - jako odmienne formy medykalizacji (deinstytucjonalizacja i deprofesjonalizacja nie są bowiem tożsame $\mathrm{z}$ demedykalizacją zaś samoleczenie czy przesadne dbanie o zdrowie ciągle opierają się na tej samej wiedzy, na której opiera się 
diagnozowanie i leczenie chorób). Autor odwołuje się także do koncepcji ryzyka, które nieuchronnie wpisane jest we współczesne społeczeństwa, czyniąc ich obywateli niepewnymi jutra i bardziej zapobiegliwymi niż kiedyś. Gdyby przywołać koncepcję płynnych czasów Baumana, można by zauważyć, że w tych ryzykownych i płynnych czasach jedynym pewnikiem w naszym życiu jest nasze ciało i stąd bierze się nieustanne zabieganie o to, by było ono w jak najlepszej kondycji. W jednym z ostatnich podrozdziałów Nowakowski pokazuje także rolę samej socjologii medycyny w kształtowaniu procesów medykalizacji - zdrowie i choroba jako konstrukty społeczne nie zależą tylko i wyłącznie od biologii i genów, są uwarunkowane poprzez wykonywaną pracę, środowisko życia, szerzej - styl życia. Stąd popularyzacja modelu socjoekologicznego, którego głównym celem jest określanie czynników ryzyka oraz prewencja i profilaktyka, podejmowane zarówno odgórnie (przez władze i instytucje), jak i oddolnie (przez jednostki). W ten sposób populacje poddawane są nieustannemu nadzorowi, a dzięki programom skriningowym eliminuje się potencjalne zagrożenia zdrowotne, podtrzymując ideał zdrowego cyberobywatela (healthy citizen) (M i a h, R i c h 2008: 53), który wszelkimi sposobami, za pomocą wszystkich dostępnych źródeł wiedzy, świadomie kreuje swoją zdrowotną trajektorię.

Książka, choć zawiera luki (jak wspomniana koncepcja Halfmanna, koncepcja farmaceutykalizacji czy odniesienia do kontekstu kulturowego), stanowi rzetelną analizę literatury przedmiotu z zakresu medykalizacji. I choć niewiele światła rzuca na procesy medykalizacji zachodzące w Polsce, to jest niewątpliwie cenną lekturą dla wszystkich, którzy planują i projektują swoje badania w tym obszarze. Świat, jaki jawi się po lekturze Medykalizacji i demedykalizacji... to świat, w którym ścierają się interesy lekarzy, pacjentów, transnarodowych koncernów farmaceutycznych, mediów, ruchów społecznych, instytucji (nie tylko medyczno-zdrowotnych), z których każda ze stron, za pośrednictwem różnorodnych działań i mechanizmów, kształtuje procesy medykalizacji i demedykalizacji. Lektura pozostawia wrażenie, że całkowita demedykalizacja nie jest właściwie możliwa, a współczesne społeczeństwa, właśnie na skutek postępu wiedzy i technologii medycznej, są bardziej schorowane niż w poprzednich stuleciach. Metafora świata jako kliniki wydaje się tu całkowicie uzasadniona i pamiętać należy, że pomimo wielu dobrodziejstw (wyeliminowanie licznych chorób, poprawa jakości życia osób niepełnosprawnych, okaleczonych, starszych, możliwość ratowania życia wcześniaków), medykalizacja niesie wiele zagrożeń, kreując nowe choroby, poszerzając kategorie diagnostyczne schorzeń już istniejących, sprzedając ludziom leki, których nie potrzebują oraz wizję zdrowia i przedłużanej w nieskończoność młodości, stając się dla wielu nową religią. 


\section{Bibliografia}

A braham J. (2010), Pharmaceuticalization of society in context: theoretical, empirical, and health dimensions, "Sociology", No. 44 (August).

B $1 \mathrm{e} \mathrm{ch} \mathrm{J.} \mathrm{(2006),} \mathrm{Inventing} \mathrm{Disease} \mathrm{and} \mathrm{Pushing} \mathrm{Pills.} \mathrm{Pharmaceutical} \mathrm{Companies} \mathrm{and} \mathrm{the} \mathrm{Medi-}$ calisation of Normal Life, Routledge, London.

Con ra d P. (2007), The Medicalization of Society. On the Transformation of Human Conditions into Treatable Disorders, The Johns Hopkins University Press, Baltimore.

$\mathrm{H}$ a $1 \mathrm{fm}$ a n $\mathrm{n}$ D. (2011), Recognizing medicalization and demedicalization: discourses, practices and identities, "Health", No. 16 (2) s. 186-207.

M i a h A., R i c h E. (2008), Medicalization of Cyberspace, Routledge, London.

M o s k a le w i c z M. (2012), Medykalizacja: patogeneza i objawy, „Czas Kultury”, nr 6.

Now a k ow s ki M. (2015), Zdrowie i choroba w czasach kapitalizmu zdezorganizowanego, Wydawnictwo Uniwersytetu M. Curie-Skłodowskiej, Lublin.

S o k oł o w s k a M. (1986), Socjologia medycyny, PZWL, Warszawa.

S zarszew ski A. (2007), Proces medykalizacji szpitali gdańskich, aspekty socjalne, prawne i ekonomiczne (1755-1874), „Annales Academiae Medicae Gedanensis”, t. 37, suplement 1.

Szasz T. (2007), The Medicalization of Everyday Life. Selected Essays, Syracuse University Press, New York.

S zas z T. (2010), The Myth of Mental Illness: Foundations of a Theory of Personal Conduct, Harper Perennial, New York.

W i e c z o r k o w s k a M. (2012), Farmaceutykalizacja spoleczeństwa-między konsumpcjonizmem a kulturq lęku, [w:] M. G ału s zk a, M. W i e c zorkowsk a (red.), Społeczne, kulturowe i polityczne uwarunkowania ryzyka zdrowotnego, Wydawnictwo Uniwersytetu Medycznego, Łódź, s. 17-37.

Willi a m s S. J., Mart in P., G a b e J. (2011), The pharmaceuticalisation of society? A framework for analysis, "Journal of Health and Illness", Vol. 33, No. 5, s. 711-725.

W o o t t o n B. (1959), Social Science and Social Pathology, The MacMillan Company, New York. 